\title{
Compressive Strength and Hydration of Ravennagrass Baggase Ash Concrete
}

\author{
Ashhabu Elkaseem \\ elkaseem77@gmail.com \\ Department of Civil Engineering, Hassan Usman Katsina Polytechnic, Nigeria \\ Samaila Bawa \\ muazubawaf@gmail.com \\ Department of Civil Engineering, Hassan Usman Katsina Polytechnic, Nigeria
}

\begin{abstract}
The paper presents the findings of the effect of revennagrass baggase ash concrete compressive strength using compression machine and hydration behavior with the aid of non-contact electrical resistivity measurement device. The result indicates that concrete containing $20 \%$ of Revennagrass Baggase Ash recorded the highest compressive strength for 1day, 3days, 7days and 28days respectively. This indicates that, the higher the increase in baggase ash the more the concrete strength up to $20 \%$ as the maximum dosage. The reverse is the case in terms of setting time, where the increase in the percentage addition brings about delay in setting time of concrete.
\end{abstract}

Keywords: Compressive strength; Baggase ash; Electrical resistivity; Admixture

\section{INTRODUCTION}

In the process of an investigation it reveals that, using waste materials always brings about positive impact for the development of any environment technically and economically (Guilherme et al., 2009). Many forms of pozzolanic materials such as fly ash, rice husk ash, silica fume to mention a few, have been used to serve as additives to our construction materials and this helps in the reduction of danger and hazard to the environment for leaving them as wastes. Sugarcane baggase ash was found to be suitable after investigation as a good pozzolanic material as it records the presence of high amorphous silica and silica content among its chemical composition (Martirena et al., 1998; Singh, 2000; Ganesan, 2007). In this study, concrete with and without revennagrass baggase ash was subjected to investigation from casting to a period of 24 hours using noncontact electrical resistivity measurement device and thereby comparing the result in terms of hydration and strength development.

\section{MATERIALS AND EXPERIMENTS}

\subsection{Materials}

Materials used in this study were ordinary Portland cement from Dangote Cement Company, Nigeria. Revennagrass baggase ash, referred to as RBAC sample was collected in Funtua Farm of Katsina State, Nigeria and burnt in boilers at a temperature ranging from 600 to $900^{\circ} \mathrm{C}$. The chemical composition for the cement and revennagrass baggase ash is as shown in Table 1 and 2 respectively. Then distilled water was used for mixing throughout the experiment. 
Table 1: Chemical composition of Portland cement

\begin{tabular}{|c|c|}
\hline OXIDES & 0 [\%] \\
\hline $\mathrm{SiO}_{2}$ & 20.02 \\
\hline $\mathrm{Fe}_{2} \mathrm{O}_{2}$ & 1.39 \\
\hline $\mathrm{Al}_{2} \mathrm{O}_{2}$ & 3.29 \\
\hline $\mathrm{CaO}$ & 69.66 \\
\hline $\mathrm{MgO}$ & 1.43 \\
\hline $\mathrm{Na}_{2} \mathrm{O}$ & 0.03 \\
\hline $\mathrm{SO}_{2}$ & 3.79 \\
\hline $\mathrm{K}_{2} \mathrm{O}$ & 0.04 \\
\hline L.O.I & 0.7 \\
\hline
\end{tabular}

Table 2: Chemical composition of revennagrass baggase ash

\begin{tabular}{|c|c|}
\hline OXIDES & $\mathbf{0}[\%]$ \\
\hline $\mathrm{SiO}_{2}$ & 59.12 \\
\hline $\mathrm{Fe}_{2} \mathrm{O}_{2}$ & 7.51 \\
\hline $\mathrm{Al}_{2} \mathrm{O}_{2}$ & 18.01 \\
\hline $\mathrm{CaO}$ & 8.42 \\
\hline $\mathrm{MgO}$ & 4.44 \\
\hline $\mathrm{Na}_{2} \mathrm{O}$ & 0.81 \\
\hline $\mathrm{SO}_{2}$ & 2.02 \\
\hline $\mathrm{K}_{2} \mathrm{O}$ & 5.01 \\
\hline L.O.I & 3.5 \\
\hline
\end{tabular}

Table 3: Mix proportion for different concrete

\begin{tabular}{|c|c|c|c|}
\hline Sample & w/c & Mix ratio & $\begin{array}{c}\text { \% Addition of } \\
\text { baggase ash }\end{array}$ \\
\hline RBAC0 & 0.50 & $1: 2: 4$ & 0 \\
\hline RBAC1 & 0.50 & $1: 2: 4$ & 10 \\
\hline RBAC2 & 0.50 & $1: 2: 4$ & 20 \\
\hline RBAC3 & 0.50 & $1: 2: 4$ & 30 \\
\hline
\end{tabular}

\subsection{Experiments}

Three different tests were conducted on the concrete with zero percentage addition of revennagrass baggase ash and similar tests were conducted to sample with percentage addition of revennagrass baggase ash. The constituents mix ratio was shown in Table 3 . The test procedures were as follows:

\subsubsection{Electrical resistivity}

The procedure for the determination of resistivity of concrete with zero percentage addition of revennagrass baggase ash and that with the percentage addition of $10 \%$, $20 \%$ and $30 \%$ respectively, represented symbolically as RBAC 0 , RBAC1, RBAC 2 and RBAC3 was performed using non-contact electrical resistivity measurement device. Mix was casted in mold and the cubes were tested for resistivity after the period of $24 \mathrm{hrs}$ hydration. The same test was performed on the concrete at different percentage addition of revennagrass baggase ash, then finally data was collected, analyzed and presented in 
our findings based on electrical resistivity measurement (Zongjin et al., 2003).

\subsubsection{Compressive strength}

Same samples were prepared and casted in 150x150x150mm molds and transferred to curing tank after period of $24 \mathrm{hrs}$ for curing before the test. The samples were later subjected to compressive strength test using compression testing machine for a period of 1 day, 3days, 7days and 28days respectively. The result is as shown in the result section.

\subsubsection{Setting time}

Setting time test was conducted to determine initial and final setting time for all samples with the aid of Vicat apparatus (ASTM C191-92, 1993).

\section{RESULTS AND DISCUSSION}

\subsection{Electrical resistivity}

Figure 1 presents electrical resistivity development $(\mathrm{P}(\mathrm{t})$ curve for different samples with and without percentage addition of revennagrass baggase ash during the first period of $24 \mathrm{hrs}$, it can be observed that, the cement with RBAC3 recorded the highest resistivity and RBAC0 with the lowest, this shows that, the higher the baggase ash the more the resistance up to $30 \%$ as in Figure 2.

Four periods were identified from a sample resistivity derivative curve on the bases of critical points pm, pa and pi which classified the hydration process. The periods include dissolution period donated with (I), induction period (II), acceleration period (III) and finally deceleration period (IV) and this conforms to similar results by Zongjin et al. (2003) and Xiaosheng et al. (2008). It was also observed that, more the percentage addition the less the conductivity of electricity as a result of pores decreasing within the cement paste. Another observation made on the curve is the inflection point, the delay was observed for the final inflection to occur as the percentage of revennagrass baggase ash decreases as in the case of RBAC3 at $16.38 \mathrm{hrs}$, which appears earlier than RBAC2 and RBAC1 at 18.45 and 19.47 hrs. respectively.

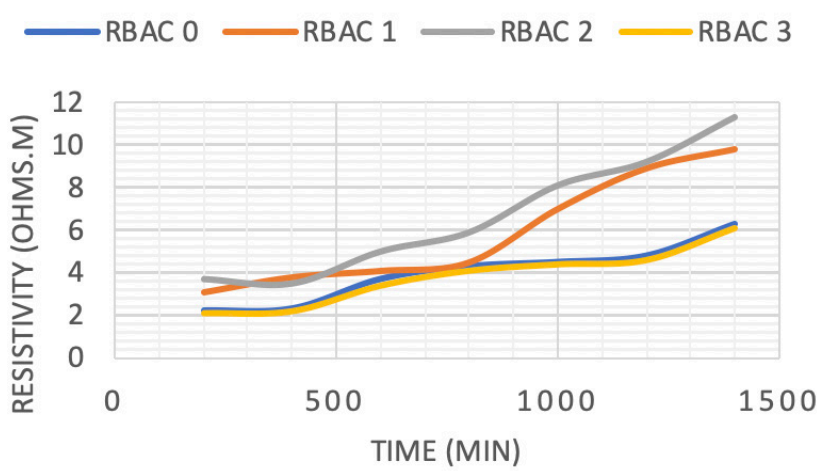

Figure 1: Electrical resistivity of baggase ash concrete for $24 \mathrm{hrs}$. 


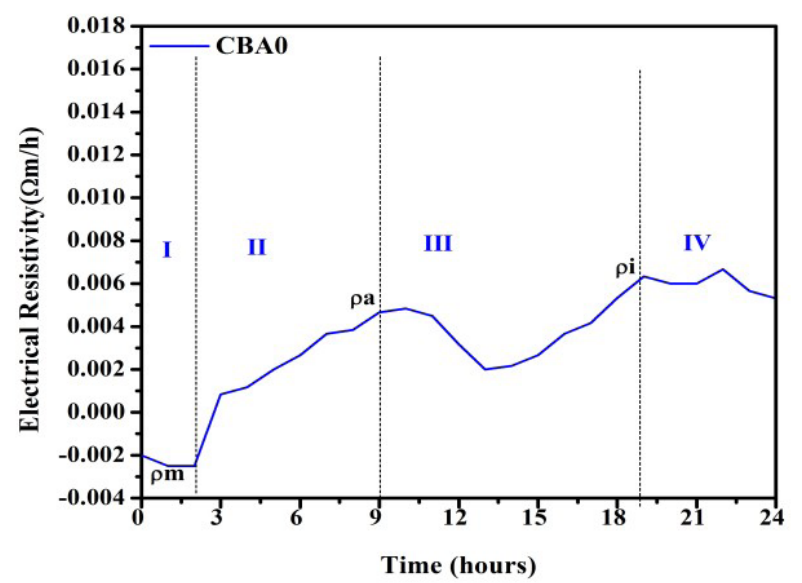

Figure 2: Samples resistivity derivative curve

\subsection{Compressive Strength}

The result which was presented in Figure 3 revealed that as it was observed in the previous study [4], RBAC2 has the highest compressive strength for 1day, 3days, 7days and 28days respectively. This shows direct effect of baggase ash to concrete strength.

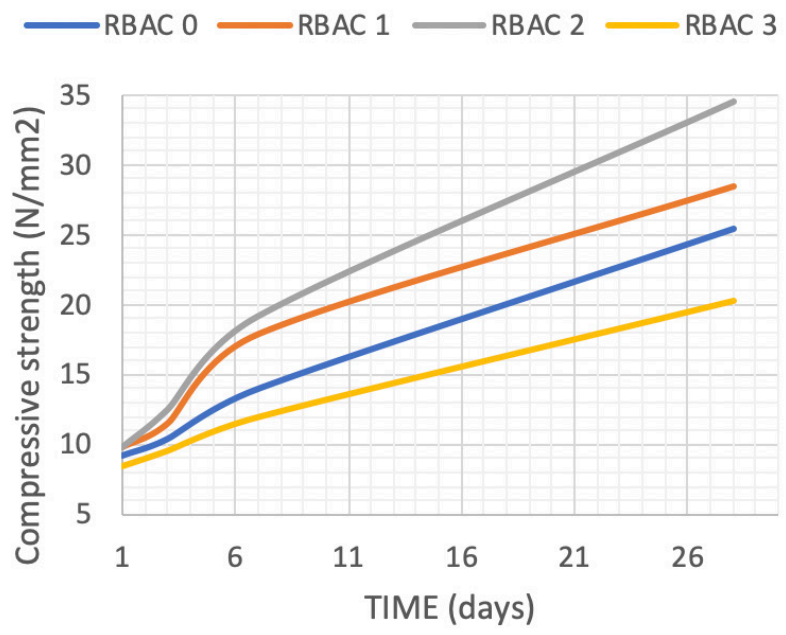

Figure 3: Compressive strength at various percentage additions

\subsection{Setting time}

It was observed that, there is a delay in the setting time of cement with the percentage addition of revennagrass baggase ash compared to that of zero percent addition as shown in Figure 4. It indicates that, baggase ash can be used as a retarder in concrete. 


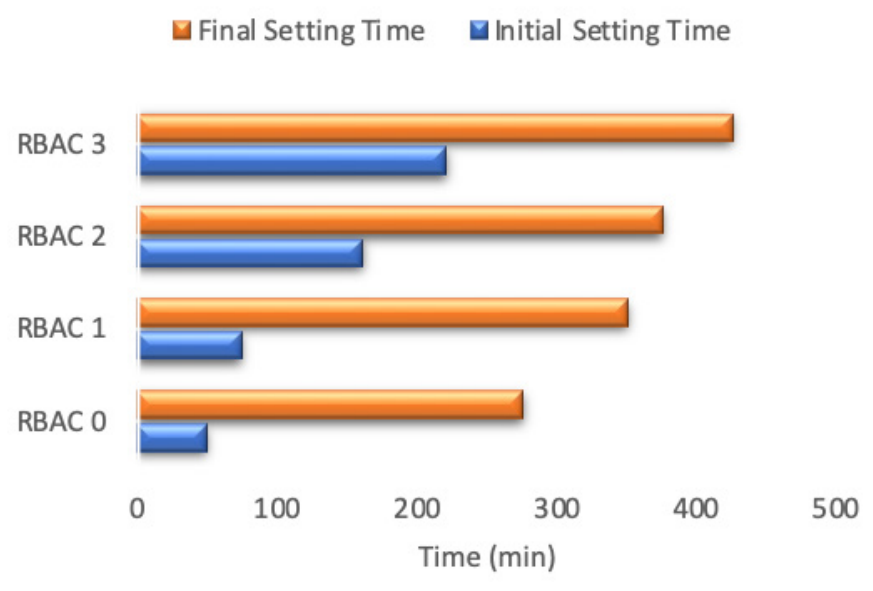

Figure 4: Initial and final setting time at various percentage addition of RBAC

\section{CONCLUSION}

This paper presents the findings of the effect of revennagrass baggase ash on concrete compressive strength and also examines hydration behavior using non-contact electrical resistivity measurement device. The result shows that, increase in the percentage addition of revennagrass baggase ash has direct bearing on increase in concrete compressive strength up to $20 \%$. This shows that, where revennagrass baggase is available, the use of its ash would substitute the expensive conventional admixtures in concrete industry. Also the delay observed in the setting time of cement with the percentage addition of baggase ash shows the suitability of the baggase ash to serve as retarder in concrete. This would allow for steady strength development in the concrete.

\section{ACKNOWLEDGMENT}

The authors wish to acknowledge the efforts of Hassan Usman Katsina Polytechnic and Tertiary Education Trust Fund Nigeria (Tetfund) for sponsoring this research.

\section{REFERENCES}

American Society of Testing Materials (1993). Standard test method for setting time of hydraulic cement, C191-92, 866-868.

Ganesan, K., Rajagopal, K. \& Thangavel, K. (2007). Evaluation of bagasse ash as supplementary cementitious material. Cem. Concr. Compos., 29(6), 515-524.

Guilherme, C. C., Romildo D. T. F., Luís M. T. \& Eduardo de M. R. F. (2009). Ultrafine grinding of sugar cane bagasse ash for application as pozzolanic admixture in concrete. Cem. Concr. Res., 39(2), 110-115.

Martirena, J. F. M. H., Middeendor, B., Gehrke, M. \& Budelmann, H. (1998) Use of wastes of the sugar industry as pozzolana in lime- pozzolana binders: Study of the reaction. Cem. Concr. Res., 28(11), 1525-1536.

Singh, N.B., Singh, V.D. \& Rai, S. (2000). Hydration of bagasse ash-blended Portland cement. 
Cem. Concr. Res., 30(9), 1485-1488.

Xiaosheng, W., Lianzhen, X. \& Zongjin, L. (2008). Electrical measurement to assess hydration process and the porosity formation. Journal of Wuhan University of Tech., 23(5): 761-766.

Zongjin, L., Xiaosheng, W. \& Wenlai, L. (2003). Preliminary interpretation of Portland cement hydration process using resistivity measurements. Material Journal, American Concrete Institute, 100(3): 253-257.

Zongjin, L., Lianzhen, X. \& Xiaosheng, W. (2007). Determination of concrete setting time using electrical resistivity measurement. Journal of materials in civil engineering, 19(5), 423-427. 